\title{
The perceived role of Islamic religiosity in minorities' educational success in Belgium. A cure or curse?
}

\section{Lore VAN PRAAG}

Ghent University, Belgium

\section{Orhan AGIRDAG}

KU Leuven, Belgium and University of Amsterdam, the Netherlands

\section{Peter AJ STEVENS \\ Ghent University, Belgium}

\section{Mieke VAN HOUTTE}

Ghent University, Belgium

\begin{abstract}
In Western Europe, Islam is largely perceived as a barrier to the integration of immigrant minorities into the mainstream and as a hindrance to educational success. However, little is known about the perceived role of Islamic religiosity (beliefs, commitments, behaviors and networks) with respect to educational success. In-depth interviews were carried out with Flemish high-school students $(N=129)$ (northern part of Belgium) in three secondary schools. Our data indicate that most respondents do not spontaneously mention religiosity as an important factor with respect to educational achievement. However, when asked directly, a significant group of Muslim students mention the memorizing of prayers as a transferable skill, the protective aspects of drug and alcohol prohibition, and the religious friends networks as a resource for fostering the feelings of school belonging. Nevertheless, some students also mention possible negative consequences due to discrimination, for example for wearing a headscarf.
\end{abstract}

\section{Corresponding author:}

Lore Van Praag, Ghent University, Korte Meer 5, Gent, 9000, Belgium.

Email: lore.vanpraag@ugent.be 


\section{Keywords}

Belgium, education, Islam, qualitative research, religiosity

\section{Résumé}

En Europe occidentale, l'Islam est largement perçu comme un obstacle à l'intégration des minorités immigrées dans la société dominante et à leur réussite scolaire. Cependant, le rapport entre la religiosité islamique (croyances, engagements, comportements et réseaux sociaux) et la réussite scolaire reste peu connu. Des entretiens approfondis ont été menés avec des étudiants $(N=129)$ en Flandre dans trois écoles secondaires. Nos données indiquent que la plupart des personnes interrogées ne mentionnent pas spontanément la religiosité comme facteur important pour la réussite scolaire. Cependant, si la question est posée explicitement, un nombre important d'étudiants musulmans mentionnent comme ressources pour réussir à l'école tant la mémorisation de prières (comme compétence transférable) que les réseaux d'amis religieux et la protection fournie par la prohibition des drogues et de l'alcool. Néanmoins, quelques étudiants mentionnent également les potentielles conséquences négatives de la religiosité islamique qu'est la discrimination.

\section{Mots-clés}

Belgique, éducation, islam, recherche qualitative, religiosité

\section{Introduction}

In contrast to the United States, where religion is seen as a route to social mobility for minorities, in Western Europe religiosity is often regarded as a barrier or a challenge to the integration of immigrants and their descendants (Foner and Alba, 2008; Güngör et al., 2011; Torrekens and Adam, 2015; Torrekens and Jacobs, 2015). Islamic religiosity in particular is a controversial topic with respect to the educational incorporation of immigrant minorities in Europe. This is also the case for Flanders, the northern part of Belgium where the present study is conducted. While large parts of Flemish society and institutions such as schools, trade unions and hospitals are organized along confessional lines, and the majority of the students in Flanders are enrolled in private (Catholic) schools (Flemish Ministry of Education, 2014), Islam is not institutionalized as an equivalent within civil society and educational institutions. There is a de facto headscarf ban in virtually all schools and teachers in public and private sectors tend to have an outspoken negative attitude towards the Islamic religiosity of their students (Agirdag et al., 2012).

Despite the public attention on controversies about Islam, relatively few European studies have examined whether and how Islamic religiosity affects students educational outcomes (for recent examples, see Agirdag et al., 2011; Byfield, 2008; Hemmerechts et al., 2014). While these studies have contributed to our knowledge of the topic, our understanding remains limited because of theoretical and conceptual shortcomings. 
Most importantly, while there is a consensus among theorists of religion that religiosity is a multidimensional concept (Cornwall et al., 1986; Glock and Stark, 1965), previous studies on this topic tend to neglect the distinct dimensions of Islamic religiosity (for example, Agirdag et al., 2011) or focus on just one dimension of religiosity, such as religious participation (Hemmerechts et al., 2014). This complicates theory-building and obscures interpretation of the results, and consequently, it is not clear which aspect of Islamic religiosity is related to educational outcomes. Secondly, the poor conceptualisation of Islamic religiosity renders the interpretation of some previous results difficult because it is not clear whether the reported consequences of religiosity are related to central dimensions of religiosity (such as religious beliefs and behaviors) or related to peripheral dimensions of religiosity (Cornwall et al., 1986). The latter are dimensions not per se related to religiosity, such as being involved in a religious community, rather than aspects that can easily be retrieved from other institutions in society such as social networks (see also Phalet and Schönpflug, 2001). Finally, a great part of previous studies focused on the issue of Islamic schools and its consequences (for example, Dwyer and Meyer, 1995), while more than 90 percent of Western Muslims attend public schools (Niyozov and Pluim, 2009).

The above mentioned lacunae motivate the research objectives of the present study. More specifically, our aim is to contribute to the existing literature by examining how different dimensions of Islamic religiosity are perceived to contribute to educational success. We will use qualitative interviews to grasp students' interpretations of their subjective religiosity, and explore how these are perceived to be related to students' school careers.

\section{Dimensions of (Islamic) religiosity}

Religiosity is best regarded as a multidimensional concept (Glock and Stark, 1965; Hill and Hood, 1999). Cornwall and her colleagues (1986) developed a useful conceptual model of religiosity. While this model is developed and employed with respect to Mormon religiosity, the aim of the authors was to develop a model of religiosity that could be translated for other religious groups. The model makes a first distinction between 'central' and 'peripheral' dimensions of religiosity.

At the central level, three general components are considered: religious beliefs, religious commitment and religious behavior. For each component, two modes are distinguished: the personal mode and institutional mode. The cross-classification of the three components of religiosity and two modes results in six central dimensions of religiosity. An example of personal religious behaviors include frequency of personal prayer which is called the Salat for Muslims; Institutional religious behaviors consist mainly of religious participation which for Muslims might be operationalized by mosque attendance. Personal religious commitment encompasses the personal affective relationship to God or Allah. Institutional religious commitment is the affective orientation of the individual towards a religious organisation or institution. Within Islam, one might think about commitment to a Madhhab (religious school of thought), to a Jamia (religious community) or to a Tariqa (religious brotherhood). Personal religious beliefs are traditional beliefs that are independent of affiliation to a particular religious 
group. For Muslims, this could be the Shahada, i.e. the belief in the oneness of God and the acceptance of Muhammad as a prophet. Finally, institutional religious beliefs refer to beliefs that are characteristic to a specific religious organisation, such as the Hanafi school within Sunni Islam. Muslims that follow this school, subscribe to the particular viewpoints of this school on the laws and obligations within Islamic law (Cornwall et al., 1986; Timmerman and Vanderwaeren, 2008).

Besides these six central dimensions, Cornwall and her colleagues (1986) also recognize some 'peripheral' dimensions such as community involvement, intellectual knowledge or religious experience. Communal involvement refers to the personal religious networks or friendships that stimulate people to engage in religious networks or in which religiosity is discussed. Another peripheral dimension is an intellectual one, and discusses the information one 'has' to know about his or her faith and the sacred scriptures. Furthermore, people may have a religious experience, for instance feeling the presence of Allah, which may affect religious feelings, beliefs and behaviors. While these dimensions might coincide with religiosity, they are not indicators of religiosity per se.

\section{Religiosity and school success}

Theoretically, both the central and peripheral dimensions of religiosity might have an influence on students' educational success. This theoretical rationale dates back to the 'founding fathers' of modern sociology. For instance, Emile Durkheim ([1897], 2006) argued that religious networks can integrate its members and it will have beneficial consequences (such as prevention of suicide), independently of the particular content of the religious beliefs. He further stated that the strength of the social integration of an individual in a religious network is stronger when a person is more engaged in (institutional) religious practices. Another pioneer of sociology, Max Weber ([1920], 2010), focused on the influence of religious beliefs on people's lives as he asserted that ascetic Protestantism triggers high aspirations, internal locus of control and values of hard work, which are clear determinants of school success (see Jones, 1997).

Drawing upon these theories, empirical studies (mostly in the US) generally found that a stronger level of Christian religiosity is positively related to academic achievement as well as health, political participation and volunteerism (see Regnerus, 2003, for a review of this literature). Additionally, research on ethnic minorities and immigrants in the US found that level of religiosity is associated with higher academic performance, even after controlling for social class (Antrop-Gonzalez et al., 2007; Jeynes, 2003). Previous research has found that religious beliefs help ethnic minority students to focus and increase their internal locus of control and study motivation (in the UK and the US, see Byfield, 2008). Religious behavior, such as church attendance, is reported to give students access to valuable social and cultural capital (in Europe see Fleischmann and Phalet, 2011; Hemmerechts et al., 2014; and in the US see Glanville et al., 2008) and contribute to the development of positive attitudes towards education, long-term future goals (in the US, see Barrett, 2010) and protection from anti-school peer networks (in Canada, see Zine, 2001). Furthermore, religious commitment can function as a source of stress relief and stress coping strategy (for example, in the US see Gartner et al., 1991). It should be noted that the resources different dimensions of religiosity offer may be of 
particular importance for more vulnerable groups in society, such as immigrants, as these groups often do not have access to other forms of social and cultural capital (Barrett, 2010; Coleman and Hoffer, 1987; Jeynes, 2003).

As shown in this literature overview, most studies report positive effects on the school careers of ethnic minorities. However, as noted by Foner and Alba (2008), the context in which these US studies are conducted varies considerably from Western Europe. These regions vary with respect to the religious backgrounds and religiosity of ethnic minority and majority groups, and historically grown relations and arrangements between state and religion. Hence, in Western Europe, religion is found to play a different role in the adaptation processes of immigrant groups in the dominant society. More specifically, religion facilitates adaptation processes in society in the US but it is often seen as a social problem in Western Europe, that hinders the integration of immigrants in society. Similar trends are also reflected in academic literature that focuses on conflicting values, social exclusion (at school), prejudices and discrimination related to Islam (Foner and Alba, 2008; Güngör et al., 2011). As a consequence, religion may affect the school career of immigrant children in Western Europe in a broader and indirect way. As this is difficult to grasp with quantitative research methods, we will make use of qualitative methods that also enable us to examine the multidimensionality of religiosity to a better extent, focusing also on which aspects of religion are meaningful to respondents and how students experience their religiosity as more and/or less beneficial to their achievement in education. Finally, to understand the religiosity of the native population and the meaning of Islam in a Flemish (educational) context, interviews with Muslim students will be compared with those of their (non-)religious classmates.

\section{Methodology}

Given the explorative nature of this research question, qualitative research methods are best suited. Ethnographic class group observations and interviews were conducted between 2009 and 2011 in three secondary schools in a large multiethnic city in Flanders. Theoretical sampling of schools was based on the track composition of the schools, the number of students of non-Belgian descent in each school and the track/field of study within a school. The three schools selected are St. Bernardus, a Catholic school that offers vocational, technical and academic tracks, with 444 students, Mountain High, a school with 1,159 students that only offers academic tracks and is run by the city authority, and Catherina Atheneum, a school funded by the Flemish government, with 404 students, that offers technical and vocational tracks. Students from nine class groups from the penultimate (fifth) year of secondary education and one additional specialization (seventh) year after compulsory secondary school were included. Including students at the end of secondary education has the advantage that they have explored their religiosity and retrospective questions can be asked that gauge the importance of religion during students' school careers. Class groups were observed in all their school activities for two or three weeks by one researcher who mainly took the role of an 'observer as a participant' (Gold, 1958) (approximately 80 hours for each group), after which semi-structured, faceto-face interviews were conducted with 129 students and 29 teachers (approximately 35 and 100 minutes). These periods of ethnographic observation allowed the principal 
Table I. Religious affiliations across ethnic descent

\begin{tabular}{lcc}
\hline Religious affiliation & \multicolumn{2}{c}{ Ethnic descent } \\
\cline { 2 - 3 } & Belgian descent & Immigrant descent \\
\hline Catholic & 9 & 4 \\
Protestant & 1 & 0 \\
Muslim & 2 & 59 \\
Not religious & 38 & 8 \\
Agnostic & 1 & 1 \\
Orthodox Catholic & 0 & 4 \\
Other & 1 & $\mathbf{7 7}$ \\
Total & $\mathbf{5 2}$ & 1 \\
\hline
\end{tabular}

researcher (female, 25 years old, without an outspoken religious affiliation) to build a more trustful relationship with the students in a context where issues such as (immigrant) religiosity, educational achievement and racism are problematized and sensitive for the actors involved. After conducting observations for several weeks in a particular class, the researcher took interviews with all the students from this particular class. These interviews began with a short written questionnaire in which questions were asked about the socio-economic background of the student, his/her educational trajectory, religious affiliation and the subjective religiosity of the student. During the interviews, students were asked about their achievements in school; definition of educational success; support from family, peers and teachers; future aspirations and educational trajectories. At the beginning of the interview, the respondents were asked to critically reflect on their definition of 'educational success'. Starting from these definitions, students were asked whether they felt their religion in some way contributed to some extent to their personal interpretation of 'success in school'. For most students, 'educational success' referred to all aspects (behavioral, academic and personal life goals) to get ahead in school and life but they rarely expanded this to include broader and more critical ideas concerning education in general.

In the sample, 47 respondents mentioned being Muslim, which was the largest religious affiliation, followed by 42 non-religious, 6 Catholic, 2 Orthodox Christians, 1 Protestant and 3 non-specified religious students. The distribution of religious affiliation for ethnic majority and minority students is shown in Table 1.

Several strategies were used to ensure the quality control of the data, such as full taperecording and transcription of the interviews, the constant comparative technique and method triangulation (for example, use of ethnographic observations, interviews and school documents) (Glaser and Strauss, 1967) to check reliability of data interpretation. An open coding scheme was used for all students, resulting in codes such as 'support from others', 'religious at home', 'perceived influence of religion at school', 'importance of aspirations for definition success', 'knowledge about religion', 'practicing', 'atheist', 'modern religion' and 'success according to religion', which formed the basis of more detailed analyses. To ensure reliability and validity, the co-authors independently reread the coding and selected quotes and provided feedback to the first author in case of disagreement regarding coding and interpretation of the quotes. The real names of the 
respondents are replaced by pseudonyms, chosen by them, to preserve the anonymity of the respondents.

\section{Results}

\section{Relevance and irrelevance of religiosity}

The results of the in-depth interviews with students indicate that, regardless of their religious affiliation, many students do not consider religiosity as very relevant with respect to their educational career and school life. This is reflected in the observation that students did not spontaneously mention religion when discussing the determinants of educational success. Even when asked directly, many students gave little weight to the role of religiosity, as illustrated by the following answers to the question 'Do you think that religion influences your school career in a possible way?':

Yasmine (Turkish descent, Muslim):

Refah (Turkish descent, Muslim):

Bilal (Moroccan descent, Muslim):

Researcher:

Bilal:
No, because I do not even notice that. I am a Muslim but that's it, I actually do not do anything for that. I do not even think about that.

Not really, you just have to work, study and that's it.

Not at school.

And outside school?

Yes, outside, then you are part of the Moroccans, do you understand?

No, you have to do it yourself, being an orthodox will not help you.

Kiril (Bulgarian descent, Orthodox Catholic):

Regardless of students' expressions of their religiosity, most respondents, both of immigrant and Belgian descent, do not feel supported or hindered by their religion in their pathway to educational success. Rather, students refer to academic behavior (like Refah or Kiril did), such as studying at home or doing their homework, as actual determinants of success, decoupling religion from profane things, like schooling. However, the importance of religion on school life varied according to immigrant status. For students of immigrant descent such as Bilal, religiosity was often interpreted as an indicator of their religious traditions, affiliation and ethnic background. For him, being a Muslim was similar to being part of the Moroccan immigrant community. These brief answers and the interchangeability between religion and students' other characteristics, indicate that most of these students did not apply a critical perspective with respect to their religion, or with regard to the relationship between religion and educational success.

Similar to students of immigrant descent, students of Belgian descent did not indicate that their religiosity played any role at school. Religion was seen by these students as a private matter (see also Vanderwaeren, 2008). Moreover, the Christian students in our sample hardly performed any religious behaviors, such as prayer or going to the church. 
Religion was often reduced to an overall feeling of being supported or their performance of a particular ritual when dealing with death and disease, as illustrated by Liselotte (Belgian descent, Catholic). She stated that: 'It is a support when something happens. When my mother was ran over by a scooter, I did a small prayer for her'. Among most students of Belgian descent, religiosity is interpreted as a tradition or (an identity) category one belongs to:

\section{Kevin (Belgian descent, Catholic):}

\section{Researcher:} Kevin:
Look, I was baptized, I did my communion. For me, that is 'being a Christian' but not believing. I want to behave like a Christian but I don't want to believe in God or in Jesus and stuff.

And why do you mention being affiliated [with Christianity]? I meet the conditions.

The accounts of Liselotte and Kevin show religiosity of students of Belgian descent is a private matter that hardly interferes with social or school life. Religious and non-religious students of Belgian descent did not see any connection between (the lack of) being religious and academic achievement for themselves. Remarkably, this contrasts with their views on immigrant religions. In line with Foner and Alba (2008), these immigrant religions in Western Europe are often perceived by the receiving society as a social problem that hinders the adaptation processes of immigrant groups in society. Often no arguments are given to explain the reasons for this negative influence of religion. Moreover, it is striking the hindering factors students refer to do not relate to Islam but to migration issues:

Researcher:

Lien (Belgian descent, not religious):

Interviewer:
You told me you were not religious. Do you think that affects in some ways your achievement in school?

I don't know. I did not experience this as such.

And when you look at others who are religious. Do you think it matters for them or not?

Lien:
Well, if you explicitly ask for it: the Islam...the Turkish girls in our class group. They often talk Turkish with each other - the entire time. You see that their Dutch language proficiency is considerably lower.

As indicated by this quote, questions about religion are often confused with ethnic or migration topics/issues, demonstrating the use of religion as a symbolic marker for other migration-related issues.

In sum, the majority of the respondents, religious and non-religious, state they do not experience a positive or negative effect of their religiosity on their academic achievement. However, for students of Belgian descent, immigrant religiosity was often perceived to hinder the educational success of students of immigrant descent, and by extension, their integration into the dominant society. Nevertheless, a smaller but significant group of Muslim students reported feeling strengthened by their religiosity, or experiencing some benefits from their religious behavior, religious beliefs, religious commitment and participation in religious networks. 


\title{
Role of religious behaviors
}

The relation between Islamic religiosity and educational processes was most apparent with respect to the behavioral component of religiosity, for both personal and institutional dimensions. Personal religious behavior, such as praying, is frequently mentioned by Muslim students as a learning facilitator, as it helps to learn how to study, how to memorize, remain calm and/or relieve stress. For instance:

Punjami (Turkish descent Muslim):

\begin{abstract}
Before I go to sleep, I learn how to study. Earlier, I always forgot what I had studied and to study too. (...) I really had to study, so my brother-inlaw came to me and said 'Well, study that, some short prayers, it will help you to learn how to study'. So I started to learn short prayers and it worked! These short prayers were so easy to study, it got straight in my head. A little bit like, studying beforehand, to train your brains. It was good. It worked out well.
\end{abstract}

For students like Punjami, religion served as a tool to memorize their curricula. The memorization of their courses may help students to succeed in some courses, such as French (as a second language), where students often have to learn lists of vocabulary. However, although students felt that their religious behavior stimulated particular forms of learning (that is, memorization, uncritical acceptance of ideas), this can be at odds with what is required by the educational system. In many courses, students have to critically reflect and understand their courses (for example, writing essays) or have to put theory into practice (especially in vocational tracks). Additionally, private religious behavior, such as praying and reading the Quran, is also mentioned as a protective force against harmful behavior, such as violence and alcohol and drug abuse:

\section{Giorgio (Turkish} descent, Muslim):

\begin{abstract}
I drank, and started smoking weed [cannabis], in third, but also in fourth year of high school, with friends, I drank myself to death, and then I even had some incidents with the police, because of my alcohol abuse, too much and too frequent (...) And then I started to realize 'Giorgio, moatje [buddy], what are you doing, everything is getting worse. So I thought, moatje, I have to stop. (...) I started to listen to Sharia4Belgium [a radical Salafist organization]. So I was looking at their videos, (...) and I realized 'these guys have a point!' so I looked at their videos and started to listen to Quran recitations, verses of the Quran (...). So I stopped, first with smoking weed, second with drinking alcohol, and then: everything! (...) Now I did not drink [alcohol] for the last year and a half and then I started praying, going to the mosque, reading the Quran and stuff. It made me more intelligent. I understand life better now and I am just a lot happier. I am quite happy with that and that's also the reason why my schoolwork is going better.
\end{abstract}

Some students considered private religious behavior as a guiding force in life, that helps to overcome problems, prevents them from performing deviant behavior (in the 
classroom) or harmful habits, like alcohol and drug abuse. As shown in this quote, Giorgio subscribes to the idea that well-being mediates the relationship between religiosity and academic achievement. In discussing how religion helped him to improve his educational career, Giorgio argues that it first helped him to develop a mature perspective on life ('to understand life better'), which in turn stimulated him to dedicate more to time to religious prayer and stop behaving in a way he considered problematic (alcohol abuse, smoking cannabis and getting involved with the police). He claims this has made him 'more intelligent' and helped him to perform better in school.

This contrasts with the interviews with the Christian respondents, who recognize the supporting role of religion in their personal life (see the Liselotte quote) but do not connect this with their school career. When students perform more religious behavior, it is more likely they will experience positive effects on their well-being and, hence, relate this to their school career. However, (personal) religious behavior might also result in experiencing discrimination, which can affect educational outcomes in a negative way. For instance Yasmina mentions social exclusion by peers from school and extracurricular activities because of the wearing of a headscarf:

Yasmina (Russian descent, Muslim):

\section{Researcher: Yasmina:}

Researcher:

Yasmina:
In my former school, we were only with three people who originated from another country and I was the only one wearing a headscarf. And when people see you wearing a headscarf, and then they look weird at you, you get other feelings

Which type of feelings?

A little bit 'left out', just being left out the school, being left out other groups of people.

And do you feel that when you take your headscarf off, that it makes a difference?

Yes, sometimes it does. When you don't wear your headscarf, they don't act that different but when you wear it, it feels like you're not part of the group. (...) For instance, when going to the cinema, when you talk with each other or keep each other company, or when you have to do some research or go out in the forest or during sport activities.

Thus, while private religious behavior is considered to enhance wellbeing, the opposite counts for students who show religious symbols and habits in public, due to social exclusion and the existence of negative religious prejudices and stereotypes. It seems that for some students, religious behavior resulted in a lack of sense of belonging at school, as they felt excluded because of the ways they were treated. Although this could affect their final achievements in school, this was not perceived as such by our respondents when discussing the impact of religion on educational success.

Moreover, students also referred to institutional religious behavior, such as activities in the mosque and Quran school, like Giorgio and Jean-Jacques did, as a positive influence. This point also emerged during the group interview with Hande and Gonca:

Hande (Turkish

descent, Muslim):

Researcher:
Islam is learning.

How do you mean? 


\begin{tabular}{|c|c|}
\hline Hande: & $\begin{array}{l}\text { You ask about religion, Islam is just learning, but in Islam, you do not } \\
\text { always learn about God, about our prophet Muhammad but also about } \\
\text { 'how you should study'. }\end{array}$ \\
\hline $\begin{array}{l}\text { Gonca (Turkish } \\
\text { descent, Muslim): }\end{array}$ & How to behave in front of your teacher. \\
\hline Hande: & $\begin{array}{l}\text { Sometimes, we even have a teacher in our mosque. We receive some } \\
\text { advice, like we have to resume a text and you have to conjugate verbs. }\end{array}$ \\
\hline Researcher: & And did it help you a lot or didn't it matter? \\
\hline Hande: & $\begin{array}{l}\text { A little bit. The teacher said 'When you study, you should leave your } \\
\text { cellphone aside or make sure it doesn't bother you. For instance, I did } \\
\text { that! Now when I study, I don't have my cellphone, so it cannot disturb } \\
\text { me anymore. }\end{array}$ \\
\hline Researcher: & Can you also give me an example? \\
\hline Gonca: & $\begin{array}{l}\text { Not really an example. We learned a lot but you cannot remember } \\
\text { everything. But we learned how to take notes. Like when the teacher } \\
\text { speaks, we had to take notes at the same time. These notes are for } \\
\text { yourself and it will help you when you want to become an Islamic } \\
\text { teacher. }\end{array}$ \\
\hline
\end{tabular}

Hande and Gonca are actively engaged in their religious community and teach Quran courses to small children of their community. They perceive the courses that are offered by their religious network, that are actually intended to improve their knowledge about their religion as courses that enhance their academic achievement. In these courses, students learn transferrable skills that are also useful at school, such as taking notes, learning how to study and the creation of a better learning environment, as well as the value of learning. These students seem to look beyond the religious character of their institutional behavior and mainly describe the perceived functions of religion for their school career, without seeing possible negative effects of their religious behavior on their educational success.

\section{Role of beliefs and commitments}

Empirically, it is hard to distinguish between religious beliefs and commitments (see also Cornwall et al., 1986). However, both are equally mentioned as facilitators of learning and as sources of motivation. For instance, Zana perceived the importance of commitment to virtues such as patience and thankfulness, which are both important Islamic virtues, as a motivating factor for school.

Researcher: $\quad$ Do you think that, at some point, religion may help or hinder you at school?

Zana (Turkish descent, Muslim): It helps me.

Researcher: In which way?

Zana:

I'll give you an example: If you fast, than you have to have a little bit of patience. So you learn how to be patient, and in life, it matters a lot. (...) In the morning, I always thank God that my physical appearance is okay. I mean: that my legs or my arms are not broken. We have enough money; I always thank God that I am alright. When I wake up in the morning 
and I think about it, then when I wake up, I am more positive. I want to work for school. I pay more attention to the courses.

As shown by Zana, religious beliefs and commitments are also seen as moral stimuli that reduce respondents' involvement with harmful behavior or violence (see also quote Giorgio):

Chris (Algerian

descent, Muslim): I would say that God is a support. I ask support from God. I think my religion, when you are a believer, you can do a lot of things with that. For instance, you are not allowed to exert violence. I am not a kind of person that would do all kinds of violence, I do not only do that because of my religion, but still, it [religion] calms me down.

While personal religious beliefs and commitments are mentioned as factors that facilitate learning and provide motivation, institutional beliefs and commitments are hardly mentioned by Muslim students in our sample. While most students mention the benefits they think they receive from their religion at school, they do not necessarily refer to exceptional features of Islam in particular. Rather, they talk about more universal religious beliefs and commitments that characterize other religions as well. With respect to religious commitment, only one Turkish girl ('Fenerli') mentioned that her participation with a religious camp gave 'meaning to her life' and motivated her to focus harder on her school career.

The absence of the institutional mode with respect to beliefs and commitments can be explained by the fact that, in contrast with Christianity, Islam does not have an elaborated tradition of religious institutions like denominational churches. Most Muslims belong to a certain Madhhab (school of thought), but these are not reflected in organizations and are far from visible in the everyday life of a Muslim.

Peripheral dimensions of religiosity. In line with the conceptual model of religiosity (Cornwall et al., 1986), students also perceived some peripheral. That is to say, students experienced positive influences of religious networks. Although networks are not uniquely related to religion, their influences are more easily established within religious communities (Coleman and Hoffer, 1987). For instance, Akon argues that being a Muslim helps in school because it facilitates his sense of school belonging or supportive peer relationships:

Akon (Ghanaian descent, Muslim):

I think that it [being a Muslim] helps me in school. You are enrolled in school with so many other Muslim boys and when you are a nonMuslim, and you go out and have lunch with a Muslim and you eat pork [haram], than I think it's more difficult to talk together. I think it is easier to talk to someone who is a Muslim, compared to someone who isn't. (...) But if you're in a class group with many other non-Muslim students, you will - how should I put it? - feel different, like 'he's a Muslim' and you'll have something like 'he's a Muslim, that's a different mentality'.

Researcher:

Akon:
What kind of mentality?

The Belgian, European one. A mentality of in which people let go things easily, they do not take things too seriously. They just have another mentality (...) When you talk to boys, like Kevin or Sven, you note 
things like 'I am a Muslim, I'm not a Muslim, religious, not religious'. (...) Let's say: a Muslim, or someone who was not born here, or someone who was born here but who was raised differently, they have a totally different mentality.

As shown in the interview extract of Akon, 'religion' is often used interchangeably with 'ethnic descent' and 'being of immigrant descent'. Akon perceives differences between ethnic minority and majority students, and relates this to their religious background. However, it is not clear to which extent these 'religious' differences are actually attributed to religion or rather to the fact that nearly all Muslim students in Flanders have an immigrant background. Nevertheless it remains important to note that, regardless of the actual reasons for these differences, Akon related this automatically to religion, demonstrating its importance as a symbolic marker that structures everyday school life and social interactions.

Although different central dimensions of religiosity are understood as a motivation to study, when discussing all possible determinants of educational success, many Muslim students automatically also see their immigrant background or the labor conditions of their immediate environment as a motivating factor for engaging in school (see also Van Praag et al., 2015):

Cimbom (Turkish descent, Muslim):

\section{Researcher: Cimbom:}

\author{
Arda (Turkish \\ descent, Muslim):
}

\section{Cimbom: \\ Arda: \\ Cimbom: \\ Researcher: \\ Arda:}
Maybe it helps you to learn a certain studying principle that you need. When you study, you need discipline and that helps.
In which way?
Well, you have certain hours or time to study, which you also need for your religion.
Maybe it's not your religion but rather culture, because in Turkish culture, when a son has studied higher studies, they say: 'His son is a doctor' and then they are proud.
Yes, proud.
This pride can also be a motivation.
Family honor.
And that's more in your culture or less?
More (Cimbom agrees) (...), when you see other people on the street, they always say [pointing at people, stating] 'he studies', so they motivate you to continue to study.

For students like Arda and Cimbom, religion is seen as one of many factors that contributes to school achievement, as it helps them to be disciplined and acquire learning methods. However, other immigrant-specific factors are mentioned as well, as a source for study motivation. Nevertheless, religion seems very important for these students as it is a way to remain in contact with other people of immigrant descent. As such, religion is a feature that unites or characterizes people of immigrant descent (to a certain extent). This is for instance visible when Powergirl (Turkish descent, Muslim) compares the Belgian people of Turkish descent with Turks that live in Turkey. She states that 'the Turks in Belgium feel more closely attached because they went to live in another country 
with another language, with another religion and stuff.' As noted by Powergirl, the immigrant community of Turkish students in the city where she lived and went to school often coincides with what she considers as a religious community: a group of people who share the same religion (Maliepaard and Lubbers, 2013; Phalet and Schönpflug, 2001). As a result, religious activities may be seen as a way to engage in the immigrant community, without actively being involved in more intensive activities that are organized by the mosque (Güngör et al., 2011).

\section{Conclusion and discussion}

The aim of the current study was to examine how Muslim students in Flanders apprehend and perceive the influence of religion/religious practices and commitments on their school career. The aim was to contribute to previous studies by disentangling various dimensions of religiosity and investigate the processes through which these dimensions affect students' educational career and school life. Based on the work of Cornwall and her colleagues (1986), we distinguished between three components of religiosity (beliefs, commitments and behaviors) that might be exerted by individuals in two modes (personal and institutional). We also made a distinction between these central aspects of religiosity and peripheral ones such as involvement in religious networks.

The results of the in-depth interviews suggest that most religious and non-religious students do not perceive a strong relationship between their (lack of) religiosity and their schooling. That is to say, students did not spontaneously mention their religiosity when discussing the determinants of educational success. Indeed, many students did not feel supported or hindered by their religion in their pursuit of educational success (see also Torrekens and Adam, 2015). While no student of Belgian descent, religious or not, perceived any relationship between religion and education in their lives, some suggested a negative effect of Islam religiosity on minorities' school success. In these accounts, religion was often compounded with issues of migration and ethnicity. Furthermore, such ideas could reflect the prevailing discourses concerning Islam and religion in Belgian society (Agirdag et al., 2012; Torrekens and Adam, 2015). For students of immigrant descent, religiosity was seen as part of their religious traditions, affiliation and ethnic background. Gans (1994) described this kind of religiosity as 'symbolic religiosity', indicating that religious symbols (for example the headscarf or a bracelet of prayer beads) are used to express their belonging to a religious community without actually practicing their religion. This kind of symbolism suggests the importance of religion in students' lives but, at the same time, reduces religion to a cultural/ethnic factor that shapes ethnic in- and out-groups and gives people a general sense of belonging. Therefore, for immigrant students who do not really want to invest in their religion and for whom religion is nothing more than a religious affiliation, religion should be considered together with their immigrant status in society, belonging and ethnic identity (for example, Korteweg and Yurdakul, 2014).

By contrast, there was a smaller but significant group of Muslim students who reported feeling mainly strengthened by their religiosity. For instance, personal religious behavior, such as the memorizing of prayers, is regarded as a transferable skill. Other personal religious behaviors such as drugs and alcohol prohibition are mentioned as protective 
aspects that might facilitate learning and discourage anti-school behavior. Personal religious commitments to Islamic virtues, such as patience and thankfulness, are mentioned as a motivating factor. However, apart from involvement in mosque activities and Quran schools, institutional aspects of religiosity are hardly mentioned. Although participation in religious networks can be regarded as personal religious behavior, many students also referred to involvement in religious networks as a factor that stimulates a sense of school belonging. Nevertheless, the latter can hardly be regarded as a central dimension of religiosity as the influence of networks is not uniquely related to religion. The only negative aspect of religiosity is mentioned when (personal) religious behavior triggers experiences of discrimination (see also Van der Bracht et al., 2013). Wearing the headscarf is, for instance, related to social exclusion by peers from school and extracurricular activities.

These findings contribute to the literature which tends to neglect the multidimensional aspects of Islamic religiosity. The fact that some students describe themselves as a religious person is not sufficient to understand how they apprehend the importance of religion in everyday lives and connect this with other outcomes. This could be due to ongoing secularization processes, displacing religion to the public sphere (Cesari, 2003; Vanderwaeren, 2008) and the entanglement between Muslim students' religious and ethnic identity (see also Zine, 2001), that characterises 'outsiders' in mainstream society. Therefore, it is more interesting to look at the different ways in which various dimensions of religiosity are present in Muslim students' public/private lives, and how students perceive how this affects their educational experiences and processes. Furthermore, these findings shed an interesting light on classical sociological theories that focus on the role of religion in society, as formulated by Durkheim ([1897], 2006) and Weber ([1920], 2010). These theories have not been developed in similar pluralist societies, such as the current Belgian society, and mainly emphasize how the cohesive and motivational role of religion in society enhances educational success but neglects or downplays the role religion can play in the creation of in- and out-groups in society and school.

These findings on the impact of religious behavior and beliefs add new insights to previous research. That is, in the literature there is more attention given to religious networks for the educational success of ethnic minorities, often starting from a social capital perspective (for example, Barrett, 2010; Coleman and Hoffer, 1987; Zine, 2001). In the present study, only a few references were made to the benefits of religious networks. This may be due to the strong overlap between students' religious and immigrant networks and the high accessibility of such religious networks for immigrants and their descendants. Therefore, a distinction should be made between students who are actively engaged in religious networks and those who merely attend the mosque and participate in (family) religious festivities, when discussing the utility of being part of religious networks for educational success. Results indicate that mainly active participants of religious networks seem to experience a clear benefit from these networks. Religion is perceived to play a role for students of immigrant descent, albeit in the ways it shapes social interactions or matter for interethnic conflict (between peers, or in student-teacher relationships). As for the (non-) religious ethnic majority students in our sample, religion was not perceived to play a substantial role in their lives, both in terms of religiosity as with respect to social life. 
It is important to mention some limitations of this study that translate into items for future research. First, the role of institutional beliefs and commitments could not be fully captured by the present study. This is partly because the sample in our study was not designed to include students that are active in various Islamic organisations such as Jamia and Tariqa. Secondly, due to the small variation in the religious diversity of this sample, no attention could be given to the religious diversity of the school context and how this relates to the development of students' religiosity and religious identity (de Hoon and van Tubergen, 2014).

Finally, this study might be an important contribution to public debates on religion and education. In contrast with the public depiction of Islamic religiosity as a mainly negative force, our results indicate that Muslim students only experience the negative effects of their religious behavior, because of the existence of prevailing negative prejudices and ideas. Moreover, when Muslim students feel their religiosity enhances their school career, this effect is mentioned to be limited but positive.

\section{Acknowledgements}

The authors would like to thank Hannah Hoechner and Julien Beghain for the proofreading of the french abstract and Koen Van der Bracht for his useful comments.

\section{Funding}

This work was supported by the Flanders - Research Foundation (FWO) under Grant FWO09/ ASP/098.

\section{References}

Agirdag O, Hermans M and Van Houtte M (2011) Het verband tussen islamitische religie, religiositeit en onderwijsprestaties. Pedagogische Studiën 88: 339-353.

Agirdag O, Loobuyck P and Van Houtte M (2012) Determinants of attitudes toward Muslim students among Flemish teachers: A research note. Journal for the Scientific Study of Religion 51: $368-376$.

Antrop-González R, Vélez W and Garrett T (2007) Religion and high academic achievement in Puerto Rican high school students. Religion and Education 34(1): 63-75.

Barrett B (2010) Religion and habitus: Exploring the relationship between religious involvement and educational outcomes and orientations among urban African American students. Urban Education 45(4): 448-479.

Byfield C (2008) The impact of religion on the educational achievement of Black boys: A UK and USA study. British Journal of Sociology of Education 29(2): 189-199.

Cesari J (2003) Muslim minorities in Europe: The silent revolution. In: Esposito J-L and Burgat F (eds) Modernizing Islam: Religion in the public sphere in the Middle East and in Europe. New Brunswick, NJ: Rutgers University Press, 251-269.

Coleman JS and Hoffer T (1987) Public and private high schools. The impact of communities. New York: Basic Books.

Cornwall M, Albrecht SL, Cunningham PH and Pitcher BL (1986) The dimensions of religiosity: A conceptual model with an empirical test. Review of Religious Research 27(3): 226-244.

De Hoon S and van Tubergen F (2014) The religiosity of children of immigrants and natives in England, Germany, and the Netherlands: The role of parents and peers in class. European Sociological Review 30: 194-206. 
Durkheim E ((1897) 2006) Suicide. Penguin: London.

Dwyer C and Meyer A (1995) The institutionalisation of Islam in the Netherlands and in the UK: The case of Islamic schools. Journal of Ethnic and Migration Studies 21(1): 37-54.

Fleischmann F and Phalet K (2011) Integration and religiosity among the Turkish second generation in Europe: A comparative analysis across four capital cities. Ethnic and Racial Studies 35(2): 320-341.

Flemish Ministry of Education (2014) Voorpublicatie Statistisch jaarboek van het Vlaams onderwijs - schooljaar 2013-2014. Available at: http://ond.vlaanderen.be/onderwijsstatistieken/2013-2014/ statistischjaarboek2013-2014/publicatiestatistischjaarboek2013-2014.htm (accessed November 4, 2014).

Foner N and Alba R (2008) Immigrant religion in the US and Western Europe: Bridge or barrier to inclusion? The International Migration Review 42(2): 360-392.

Gans HJ (1994) Symbolic ethnicity and symbolic religiosity: Towards a comparison of ethnic and religious acculturation. Ethnic and Racial Studies 17(4): 577-592.

Gartner J, Larson DB and Allen GD (1991) Religious commitment and mental health: A review of the empirical literature. Journal of Psychology and Theology 19(Spring): 6-25.

Glanville J, Sikkink D and Hernandez E (2008) Religious involvement and educational outcomes: The role of social capital and extracurricular participation. The Sociological Quarterly 49(1): 105-137.

Glaser BG and Strauss A (1967) The discovery of grounded theory: Strategies for qualitative research. Chicago: Aldine.

Glock CY and Stark R (1965) Religion and society in tension. Chicago: Rand McNally.

Gold RL (1958) Roles in sociological field observation. Social Forces 36(3): 213-217.

Güngör D, Fleischmann F and Phalet K (2011) Religious identification, belief, and practice among Turkish- and Moroccan Belgian Muslims: Intergenerational continuity and acculturative change. Journal of Cross-Cultural Psychology 42(8): 1356-1374.

Hemmerechts K, De RoeckF, Kavadias F and Agirdag O(2014)Het effect van immigratieachtergrond op de onderwijsverwachtingen van leerlingen in Vlaanderen: de rol van religieuze affiliatie en praktijken. Tijdschrift voor Onderwijsrecht en Onderwijsbeleid 13: 16-28.

Hill PC and Hood RW Jr (1999) Measures of Religiosity. Birmingham, AL: Religious Education Press.

Jeynes WH (2003) The effects of religious commitment on the academic achievement of urban and other children. Education and Urban Society 36(1): 44-62.

Jones H Jr B (1997) The Protestant Ethic: Weber's model and the empirical literature. Human Relations 50(7): 757-778.

Korteweg AC and Yurdakul G (2014) The headscarf debates. Conflicts of national belonging. Stanford, CA: Stanford University Press.

Maliepaard M and Lubbers M (2013) Parental religious transmission after migration: The case of Dutch Muslims. Journal of Ethnic and Migration Studies 39(3): 425-442.

Niyozov S and Pluim G (2009) Teachers' perspectives on the education of Muslim students: A missing voice in Muslim education research. Curriculum inquiry 39(5): 637-677.

Phalet K and Schönpflug U (2001) Intergenerational transmission of collectivism and achievement values in two acculturation contexts. The case of Turkish families in Germany and Turkish and Moroccan families in the Netherlands. Journal of Cross-Cultural Psychology 32(2): 186-201.

Regnerus MD (2003) Religion and positive adolescent outcomes: A review of research and theory. Review of Religious Research 44(4): 394-413.

Timmerman C and Vanderwaeren E (2008) Hoogopgeleide jongeren over hun moslim zijn in Vlaanderen. In: Vanderwaeren E and Timmerman C (eds) Diversiteit in Islam. Over verschillende belevingen van het moslim zijn. Leuven: Acco, 15-44.

Torrekens C and Adam I (2015) Marokkaanse en Turkse Belgen: een (zelf-portret van onze (mede) burgers. Brussels: Koning Boudewijnstichting. 
Torrekens C and Jacobs D (2015) Muslims' religiosity and views on religion in six Western European countries: does national context matter? Journal of Ethnic and Migration Studies, 42(2): 325-340.

Vanderwaeren E (2008) Religieuze beschouwingen onder hoger opgeleide moslims. In: Vanderwaeren E. and Timmerman C (eds) Diversiteit in islam. Over verschillende belevingen van het moslim zijn. Leuven: Acco, 45-72.

Van der Bracht K, Van de Putte B and Verhaeghe P-P (2013) God bless our children? The role of generation, discrimination and religious context for migrants in Europe. International Migration 51(3): 23-27.

Van Praag L, D'hondt F, Stevens PAJ and Van Houtte M (2015) Is the sky really the limit? Exploring the attitude-achievement paradox in the Belgian context. Sociology of Race and Ethnicity 1(2): 225-238.

Weber M ((1920) 2010) The protestant ethic and the spirit of capitalism. New York: Oxford University Press.

Zine J (2001) Muslim youth in Canadian schools: Education and the politics of religious identity. Anthropology and Education Quarterly 32(4): 399-423.

\section{Author biographies}

Lore VAN PRAAG is working as a post-doctoral researcher at the RESL.eu project. Her research interests are interethnic relations in schools, tracking, discrimination, educational achievement, early school leaving, and ethnography.

Address: Korte Meer 5, 9000 Gent, Belgium.

Email: Lore.VanPraag@UGent.be

Orhan AGIRDAG is a professor at KU Leuven, Belgium, and the University of Amsterdam, the Netherlands. His research focuses on the impact of societal tendencies upon educational and learning processes.

Address: KU Leuven: Andreas Vesaliusstraat 2 - bus 37613000 Leuven, Belgium; University of Amsterdam: Postbus 15780; 1001 NG Amsterdam, The Netherlands.

Email: orhan.agirdag@gmail.com

Peter A. J. STEVENS is working as a professor at Ghent University. His research interests cover the sociology of education, race and ethnic relations and international comparative research.

Address: Universiteitsstraat 8, 9000 Gent, Belgium.

Email: Peter.Stevens@UGent.be

Mieke VAN HOUTTE is a professor at Ghent University. Her main research interest is educational inequality and the effects of structural and compositional school features on various outcomes of students and teachers.

Address: Korte Meer 5, 9000 Gent, Belgium.

Email: Mieke.VanHoutte@UGent.be 